\title{
Vladimír Helfert, zakladatel Hudebního archivu Moravského zemského muzea
}

\section{Vladimír Helfert, a Founder of the Music Archive of the Moravian Museum}

Ondřej Pivoda / pivoda@mail.muni.cz

Ústav hudební vědy FF MU; Oddělení dějin hudby MZM, Brno, CZ

\begin{abstract}
A foundation of the Music Archive of the Moravian Museum is connected with a relocation of Vladimír Helfert to Brno in 1919. Vladimír Helfert's idea to establish a modern music archive could realize due to cooperation with Vladimir's brother Jaroslav who worked as a secretary of the museum and since 1923 as its director. A development of the archive was initiated by acquiring a precious music collection from the Strážnice castle. Efforts of the Helfert brothers crossed with the endeavour of the Ministry of Education and National Culture to ensure a preservation of historic monuments which were endangered by potential export to Austria, Hungary etc. after the constitution of the Czechoslovakia in 1918. For that reason it was necessary to make quickly a register of those monuments. A base for creating a register and for subsequent preservation of the monuments of music was established by the Council of the Music Archive of the Moravian Museum in 1920. It consisted of the music conservators nominated for the Moravia and Silesia region by the Ministry of Education and National Culture. Vladimír Helfert was appointed as the Councils secretary. Activities of the Council consisted in preserving monuments of music, in creating its register and in collecting of the monuments in order to create a music archive. A proposal of the statutes of the Central Council for Preservation of Monuments of Music in the Czechoslovak Republic was a collective work by Vladimír and Jaroslav Helfert. In the statutes they divided a scope of authority amongst the work groups in Prague, Brno and Bratislava and included i.a. a plan on founding the State Music Archives and Museums in Prague and Bratislava. But the activities of Vladimír Helfert were primarily focused on organization of the Music Archive in Brno. He set down the principles of cataloguing and segmentation of the music collection of the archive and in cooperation with his first colleagues, the musicologists Karel Vetterl and Jan Racek, he created a solid basis for the development of the institution. Thanks to Vladimír Helfert the Music Archive of the Moravian Museum ranked soon among the most important and the most modern institutions of its kind in Europe.
\end{abstract}




\section{Key words}

Vladimír Helfert, Jaroslav Helfert, Music Archive of the Moravian Museum, music conservators, monuments of music

Příspěvek se pokouší načrtnout portrét Vladimíra Helferta coby zakladatele Hudebního archivu Moravského zemského muzea, a to nejen přiblížit jeho zásluhy a podíl v této věci, nýbrž především popsat pohnutky, které Helferta k založení brněnského hudebního archivu vedly, a předpoklady, jež bylo pro vznik archivu a jeho fungování nutno uskutečnit.

Helfertova myšlenka zřídit hudební archiv v Brně se mohla realizovat především díky několika důležitým a nezbytným okolnostem. Svůj nepominutelný význam mělo několik na první pohled samozřejmých historických událostí: příchod Vladimíra Helferta do Brna, pád Rakouska-Uherska a vznik Československé republiky, kdy rozpad monarchie na konci roku 1918 vyvolal vědomí nutnosti systematické ochrany a evidence hudebních památek.

\section{Př́chod Vladimíra Helferta do Brna}

Rozhodnutí přesídlit do Brna dozrávalo v mysli Vladimíra Helferta poměrně dlouhou dobu. Po dokončení univerzity působil Helfert od září roku 1909 jako profesor dějepisu a zeměpisu na Českoslovanské obchodní akademii v Praze. Roku 1910 se oženil s Blaženou Brichtovou, jejíž sestra byla manželkou Zdeňka Nejedlého. V relativně krátké době po sobě pak přišli na svět jeho tři potomci - dcery Blažena (*1911) a Renata (*1913) a syn Igor (*1915). Z korespondence s bratrem Jaroslavem, který od roku 1909 působil jako sekretář Moravského zemského muzea v Brně, jasně vyplývá, že Vladimír uvažoval o odchodu do Brna již před vypuknutím první světové války. V dopise ze 7. ledna 1913 zmiňuje Jaroslav blíže nespecifikovanou pozici, o níž Vladimír v Brně zřejmě usiloval:

„Milý Vlád'o, definitivní odpověd' na Tvưj dopis nemohu Ti dnes ještě dáti. O Tvé kandidatuře mluvi se již mezi naším kroužkem (který dnes má hodně váhy) docela vážně. Kdy k systematisováni mista dojde nevim; záleži však také do jisté míry na nás, abychom návrh na systematisování způsobili. "1

O konkrétních podnětech, jež vedly Vladimíra Helferta k myšlence přesunout své působiště do Brna, doklady nemáme, můžeme se o nich jen domnívat a usuzovat. Hlavním motivem byla nejspíše snaha realizovat se v profesi, která by souvisela s činností hudebně vědeckou, respektive hudebně organizátorskou, a jejímž prostřednictvím by Helfert mohl ovlivňovat a působit na český hudební život. K dosažení takového místa se v Brně naskýtaly výhledově lepší podmínky než v Praze. Vezmeme-li v úvahu stav hudebního života v Brně před rokem 1918, mohl Helfert coby odborně vzdělaný hudební vě-

1 Dopis Jaroslava Helferta Vladimíru Helfertovi, 7. 1. 1913. Oddělení dějin hudby Moravského zemského muzea (dále jen ODH MZM), sign. B 281. 
dec budovat v Brně prakticky vše „na zelené louce“. O tom uvažoval již roku 1918 ve své kritické studii Naše hudba a český stát, kde píše:

„Pokud dá se předvídat z dně̌niho stavu hudebního života na Moravě (o slezském a slovenském zatím nelze mluvit), vyvinou se př̌šti poměry pravděpodobně tak, že kulturním střediskem východni skupiny zemi českého státu (Moravy, Slezska a Slovenska) bude Brno. Tím stane se Brno $i$ střediskem kulturního života těchto zemí, podobně jako Praha je centrem uměleckým a kulturním pro Čechy. Pak ale otázka samostatného zemského divadla v Brně a samostatného orchestru koncertniho a konservatoře zemské bude posunuta do stadia nezbytného praktického rozřěsení. V Brně vykvete nový hudebni život, který podstatně obohati naši celou hudebni kulturu. Na jakých konkrétnich základech by mohl a měl tento nezrozený dosud život postaven, o tom přinese tato knihovna speciálni studii. Zde budiž jen tolik poznamenáno, že našim pražským hudebnim poměrum je nezbytně třeba, aby vedle nich vyrostlo nové středisko hudební. Jinými slovy: našemu hudebnimu životu je třeba zdravé umělecké konkurence. "2

Při Helfertově rozhodování hrála patrně roli i potřeba osamostatnit se a vymanit se ze stranictví a politikaření, jímž byl v předpřevratové době pražský hudební život nasáklý (vzpomeňme jen na spory smetanovců a dvořákovců, do nichž byl Helfert také zapleten). Podíl na Helfertově odchodu do Brna mohla mít i snaha zbavit se vlivu, který v Praze ve svých rukou držel Zdeněk Nejedlý. Pro mladého Helferta zajisté nebylo snadné prosadit rozdílný názor proti Nejedlému. Jednak byl Nejedlý vưči Helfertovi v pozici jeho učitele a mentora, jednak bylo nutno brát ohledy na vzájemnou rodinnou spř́ízněnost.

Od podzimu roku 1917 je z dopisů bratra Jaroslava znatelná zvýšená intenzita Vladimírových snah dostat se do Brna. Dne 24. ř́ijna 1917 reaguje Jaroslav v odpovědi na Vladimírův dopis následovně: „Kdyby se brzo uskutečnil Toůj plán, jíti do Brna, byl bych moc rád. Budu hledět něco vyzvědět a hned Ti napiši. Máš pravdu, že bys tu rád byl už před koncem války. Nebot’ práce se zde musí začít už nyni, do nových poměrů musím mít už něco připraveno. "3

Dne 7. dubna 1918 posílá Jaroslav bratru inzerát z Lidových novin o vypsání profesorských míst při c. k. státní průmyslové škole v Brně, mj. pro dějepis a zeměpis a píše: „Milý Vlád’o, na zdejši prümyslové vyšši škole obsadi se misto definitivního historika. Je to výborná štac, nejlepši ze střednich ústavů, žádný inspektor, žádný fland'ák, podléhá přimo min. veř. prací. Je to ústav, o kterém jsem s Tebou už mluvil při plánech Tvých s Brnem. Nyni tedy je výborná přiležitost!! Nevím, zda máš nyni náladu na to myslit, ale přece jen to uvaž. Šlo by to konečně spojit s Tuým plánem, který odkládáš až do prázdnin. " Vladimír obratem telegraficky zájem o místo potvrdil, tato příležitost však ztroskotala na problémech s doložením vysvědčení zachovalosti.

O několik měsíců později 16. září 1918 znovu informoval Jaroslav Vladimíra o možnosti nastoupit na suplentské místo na brněnské reálce. Zde byl ovšem překážkou fakt, že by si přijetím tohoto místa Vladimír Helfert finančně pohoršil, což bylo pro živitele manželky a tří dětí zřejmě nepřijatelné. Dne 8. února 1919 sděluje Jaroslav Vladimírovi, že „s otázkou brněnské konservatoře se nyni energicky hýbe; pákou je Janáček a proto má obavy,

2 HELFERT, Vladimír. Naše hudba a český stát. In HELFERT, Vladimír. Vybrané studie I. O hudebni tvořivosti. Praha: Editio Supraphon, 1970. s. 29-53.

3 Dopis Jaroslava Helferta Vladimíru Helfertovi, 24. 10. 1917, ODH MZM, sign. D 363.

4 Dopis Jaroslava Helferta Vladimíru Helfertovi, 7. 4. 1918, ODH MZM, sign. B 229. 
aby ten podnik nedostal hned do vínku zárodek neduživosti “. ${ }^{5}$ Myslí i na bratrovu kandidaturu a radí mu, aby v té věci nic nezmeškal. Jak vyplývá z korespondence mezi bratry, zasazoval se o povolání Helferta na konzervatoř údajně i Janáček, ale bylo prý to (neznámo jak) zmařeno. $\mathrm{V}$ úvahu poté připadalo místo úředníka, jež bylo vypsáno v brněnské zemské knihovně. Uchytit se v Brně se však Helfertovi podařilo až po vypsání dvou definitivních profesorských míst v březnu 1919 na brněnském I. gymnáziu a na II. reálce pro dějepis a zeměpis. Od září 1919 byl Helfert s konečnou platností jmenován profesorem gymnázia ve Vyškově, avšak službou přikázán do Brna, nejprve na I. (do roku 1921), posléze na II. státní reálku (do roku 1926).

Své dojmy a neskromné plány s Brnem nadšeně sděloval v dopise příteli Vojtovi Matysovi 17. září 1919: „Do Brna jedu rád. Mám četné plány. Předně chci se habilitovat pro zdejši universitu. Pak chci také trochu vzít do ruky hudebni život a vỉbec byl bych rád, aby z Brna co nejdřive stalo se druhé české kulturni středisko. Rád bych to i kvĩli Praze, nebot' tohleto dosud Praze chybělo a tím tam mohlo rozbujet ono [...?...] $]^{6}$ a úžasné stranictvi. "7 Týden před tím se s Helfertem v Praze rozloučil Zdeněk Nejedlý a jak je zřejmé z jeho dopisu z 10. září 1919, podporoval i Helfertovu myšlenku založení hudebního archivu, kterou se Helfert chystal ve svém novém působišti uskutečnit: „K Tvému dopisu stran hud. archivu v Brně odpovidám jen stručně, že docela s tím souhlasim, a pokud na mně jest, že v tom $i$ ve všem ostatním budu vždy pro takovou decentralizaci, která je jenom zdravá. Jen Tě prosím, abys mne vždy ve v̌̌em $v$ čas informoval, abychom i tak pracovali vždy jednotně a tím se zdarem. "8

\section{Vědomí nutnosti systematické ochrany a evidence hudebních památek}

Česká muzikologie byla v době svého vzniku orientována výlučně historicky, a to především díky Zdeňku Nejedlému, faktickému zakladateli tohoto oboru v českém prostředí, jenž byl roku 1908 jmenován a roku 1909 ustanoven mimořádným profesorem pro obor hudební věda na Karlově univerzitě. Zdeněk Nejedlý byl zaměřením i vzděláním především historik (žák Jaroslava Golla a Otakara Hostinského), což se obráží i ve velké většině jeho prací. Nelze přehlížet, že z myšlenkového okruhu Nejedlého vyšel i Vladimír Helfert. Ten si metodologickou potřebu syntézy hudební vědy historické a systematické (řečeno terminologií Adlerovy oborové systematiky) plně uvědomil až ve 20. letech jako univerzitní profesor hudební vědy na Masarykově univerzitě v Brně. Prvé Helfertovy větší muzikologické práce $\mathrm{K}$ dějinám melodramatu. Jiří Benda a Jean Jacques Rousseau (disertace, 1908), především pak Hudební barok na českých zámcích, Jaroměřice za hraběte Jana Adama z Questenberka (vyd. 1916) a Hudba na jaroměřickém zámku, František Míča 1696-1745 (habilitace, 1921) poukazují právě na onu pozitivistickou historiogra-

5 Dopis Jaroslava Helferta Vladimíru Helfertovi, 8. 2. 1919, ODH MZM, sign. D 347.

6 Nečitelné slovo.

7 Dopis Vladimíra Helferta Vojtovi Matysovi, 17. 9. 1919, ODH MZM, sign. B 1258.

8 Dopis Zdeňka Nejedlého Vladimíru Helfertovi, 10. 9. 1919, ODH MZM, sign. A 1.420. 
fickou linii Gollovu a na historicko-srovnávací postupy školy Hostinského. Znatelné je ovšem i zdůraznění sociálně-funkčních vazeb hudby, které vnesl do české hudební historiografie právě Zdeněk Nejedlý. Svou pečet zanechaly ve zmíněných Helfertových spisech také názory Adlerovy, vyjádřené v jeho pojednání Der Stil in der Musik.

Helfertova díla o hudbě 18. století se samozřejmě neobešla bez důkladných a časově náročných pramenných výzkumů a studia. Překážky a problémy týkající se srovnávacího materiálu, tj. chybějících nebo nepřístupných historických dokumentů, na něž bezesporu při své práci narazil, stejně tak jako poznání velkých moderních hudebních archivů v Německu, Francii, Itálii aj. patrně podnítily Vladimíra Helferta k myšlence soustavné a jednotné evidence hudebních pramenů na českém území, jež by mohla značnou měrou zjednodušit a prohloubit vědecké bádání o hudbě starších historických údobí. Česká hudební historiografie ve smyslu historické a stylové kritiky hudebních pramenů byla dle Helfertových slov „dosud budována ,shora“, ale na základy se zapomnělo“9. Helfert si velmi dobře uvědomoval potřebu vybudování pramenné základny pro rozvinutí hudebně historiografického bádání o hudbě na Moravě a skutečnost, že vybudování archivu by podpořilo a podepřelo práci hudebněvědeckého ústavu na brněnské univerzitě.

Vlastní ochrana hudebních památek byla doménou spíše Vladimírova bratra Jaroslava, který, jak již bylo řečeno, od roku 1909 působil jako sekretář (tajemník) Moravského zemského muzea v Brně. Aktuálnost otázky ochrany památek urychlil pád Rakouska-Uherska, kdy těsně po vyhlášení samostatnosti Československa 28. října 1918 bylo nutno rychle zajistit významné a umělecky hodnotné výtvarné památky na území Čech a Moravy, aby nebyly vyvezeny do zahraničí. Jaroslav Helfert byl jako člen popřevratového Národního výboru v Brně pověřen dozorem v této záležitosti pro celou Moravu a Slezsko ${ }^{10}$. Pod jeho dozorem byl zajištován a sepisován zejména majetek německé šlechty - Lichtenštejnů, Dietrichštejnů apod. Za tímto účelem byl Jaroslav Helfert nucen konat četné inspekce po Moravě. Při cestě do Strážnice v květnu 1919 zde objevil pozoruhodný hudební materiál, o jehož převedení do brněnského muzea ihned zahájil jednání. ${ }^{11}$ Tyto sbírky byly následně získány díky iniciativě a ochotě majitele zámku Antonína Magnise a vytvořily tak faktický základ Hudebního archivu Moravského zemského muzea.

Z této popřevratové atmosféry byl při Ministerstvu školství a národní osvěty (MŠANO) vytvořen hudebně památkový sbor, který výnosem z 10. února 1919 jmenoval konzervátory hudebních památek, a zároveň vydal speciální instrukce pro soupis hudebnin a hudebních nástrojů. Činnost konzervátorů byla formulována především jako zpravodajská a soupisná. Jejich úkolem bylo podávat informace o nálezech či ohrožených památkách, poskytovat rychlou iniciativu k zakročení v nebo k získání památky ohrožené a pořizovat soupis historicky cenných hudebnin a hudebních nástrojů do roku 1860. Konzervátoři byli jmenováni na dobu jednoho roku s působností pro určitou oblast, výjimečně i pro celou Československou republiku (např. Leoš Janáček).

9 HELFERT, Vladimír. Úkoly české hudební historiografie. Naše věda. Kritický měsičnik 9, 1927-1928, s. 19-27.

10 Jaroslav o tom informuje bratra Vladimíra v dopise z 30. 10. 1918. ODH MZM, sign. B 309.

11 Dopis Jaroslava Helferta bratru Vladimírovi, 26. 5. 1919, ODH MZM, sign. D 420. 


\section{Konzervátoři jmenovaní pro Moravu a Slezsko:}

- Hynek Bím, ředitel měštanské školy dívčí v Uherské Skalici,

- Gracian Černušák, profesor obchodní akademie v Brně,

- Bohuslav Fischer, profesor v Uherském Hradišti,

- Jaroslav Granát, profesor v Brně,

- Jaroslav Helfert, tajemník zemského muzea v Brně,

- Jan Kakš, finanční rada v Brně,

- Jaroslav Budík, kapelník v Moravské Ostravě,

- Jaroslav Čeleda, houslista v Bzenci,

- Václav Hobzík, řídící učitel měštanské školy v Opavě.

\section{Činnost Rady Hudebního archivu v Brně}

Díky všem těmto okolnostem mohlo konečně dojít k samotnému aktu založení Hudebního archivu při Moravském zemském muzeu. Archiv byl de facto zřízen získáním hudebnin ze zámku ve Strážnici, dále převedením hudebních památek ze sbírek Moravského zemského muzea (hudebnin, divadelních cedulí a hudebních nástrojů) do speciálního hudebního archivu a ziskem finančních prostředků na jeho činnost. Archivu byla přidělena podpora v rámci rozpočtu muzea a navíc byla získána státní dotace přidělovaná MŠANO. Právnímu podkladu se archivu dostalo ustavující schůzí Rady hudebního archivu zemského muzea v Brně dne 17. října 1919 a předběžným schválením Rady příslušnými úředníky MŠANO a zemským výborem. Ze strany obou institucí (zejména ministerstva) pak bylo žádáno vypracování stanov, statutu Rady hudebního archivu.

Zakládajícími členy Rady se stali: Jan Kakš (předseda), ${ }^{12}$ Gracian Černušák (místopředseda), Vladimír Helfert (jednatel a správce archivu), Jaroslav Helfert (zástupce muzea) a Jaroslav Granát. ${ }^{13}$ Radě se během dvou let 1919-1921 podařilo rozvinout rozsáhlou a plodnou činnost zaměřenou k vybudování prvního výlučně vědecky koncipovaného hudebního archivu v Československu. Na žádost moravského zemského výboru a MŠANO vypracoval Vladimír Helfert ve spolupráci s bratrem Jaroslavem Statut Rady Hudebního archivu Moravského zemského musea v Brně. ${ }^{14}$ Jako hlavní úkol této instituce byl stanoven sběr a soustřed'ování hudebních památek z Moravy a Slezska, jejich odborné třídění a zpracovávání. Podrobná specifikace předmětů sbíraných hudebním archivem z pera

12 Jan Kakš (1867-1955), povoláním právník, finanční rada. Byl prvním dirigentem Orchestrálního sdružení v Brně (1906-19007), psal hudební referáty do Hlídky a Hlasu a podílel se organizátorsky na činnosti Družstva Národního divadla v Brně. V letech 1916-1919 vyučoval dějiny hudby na brněnské Varhanické škole, dále na Hudební škole Besedy brněnské (1918-1919) a na nově založené brněnské konzervatoři (1919-1920). Krátce po vzniku Rady hudebního archivu Moravského zemského muzea přesídlil do Prahy.

13 Jaroslav Granát studoval slovanskou a germánskou filologii na Karlově univerzitě, již během studií udržoval kontakty s Vladimírem Helfertem. Pravděpodobně v roce 1918 se usídlil v Brně, kde byl středoškolským profesorem. V letech 1919-20 působil jako dirigent Orchestrálního sdružení v Brně. Také on odešel krátce po založení Rady hudebního archivu do Prahy.

14 Statut Rady hudebního archivu moravského zemského musea v Brně, stanovy, jejich rukopisný a strojopisný koncept uložen v Archivu Oddělení dějin hudby MZM. 
Vladimíra Helferta svědčí o jeho neochvějném povědomí o tom, které prameny jsou pro historické bádání o hudbě primárně důležité, a prokazují Hefertovy bohaté zkušenosti načerpané při práci na monografiích o J. A. Bendovi a hudebním životě na jaroměřickém zámku. Hudební archiv tak dle Helfertových směrnic započal se shromažd’ováním rukopisných hudebnin, historicky cenných tisků, dopisů a listin vztahujících se k hudbě, divadelních cedulí a programů koncertů, operních a oratorních libret, rukopisných katalogů hudebních sbírek a hudebních knihoven, podobizen hudebníků a historicky cenných hudebních nástrojů. ${ }^{15}$ Podobně pokrokové bylo rovněž vytýčení funkce archivu jako instituce $s$ úkoly čistě vědeckými a vymezení se vưči institucím, které plnily v prvé řadě úkoly výchovné, tj. zejména vůči hudebním archivům při konzervatořích. Neméně důležitou aktivitou Hudebního archivu bylo pořizování soupisu hudebních památek. Zásluhou Vladimíra Helferta byla evidence vedena pomocí katalogových karet se základními údaji o hudebnině, k nimž byl připojen několikataktový hudební incipit dané skladby po vzoru moderních tematických katalogů. ${ }^{16}$

Již od počátku se Rada Hudebního archivu snažila získávat kontakty na moravském venkově a kooptovat nové členy z řad dalších ministerstvem jmenovaných konzervátorů. Členové Rady se také pokusili vytvořit sít externích spolupracovníků či důvěrníků, kteří by mohli Radu informovat o cenných hudebních památkách v daném regionu, eventuálně je zabezpečit nebo zprostředkovat jejich získání pro Hudební archiv. ${ }^{17}$ Za účelem organizování konzervátorských prací na Moravě, zabezpečování hudebních památek a získávání spolupracovníků pak konali jednotliví členové Rady četné cesty po moravském venkově. Rada rovněž vypracovala dotazník, jenž byl otištěn v časopise Hudební výchova a rozeslán správám krajinských a městských muzeí, ředitelům kůrů, farním úřadům, správám velkostatků, správám měštanských, obecných i středních škol. ${ }^{18}$ Jeho prostřednictvím se Rada snažila vyzískat informace o místních historicky cenných hudebních památkách.

Přičiněním Jana Kakše byly ihned v počátku působení Rady Hudebního archivu získány materiály z ivančického kůru a z rajhradského kláštera ${ }^{19}$, dále archiv Pěveckého sdružení moravských učitelů a hudebniny z Horáckého muzea v Novém Městě na Moravě. Jednotliví členové Rady v prvním roce působení vykonali prohlídky hudebních památek mj. v Rajhradu, ${ }^{20}$ Napajedlech (zámek), ${ }^{21}$ Brtnici (zámek a kostel), ${ }^{22}$ Náměšti nad Oslavou

15 Ibid. a v zápise ze schůze Rady hudebního archivu, 24. 10. 1919, Archiv Oddělení dějin hudby MZM, č. $13 / 19$.

16 Za upozornění na tento fakt děkuji prof. Jiřímu Sehnalovi.

17 K organizaci důvěrníků viz zvláště průklep dopisu Rady Hudebního archivu MŠANO, 17. 2. 1920, Archiv Oddělení dějin hudby MZM, č. 13/20.

18 Protokoly č. 10/20 a č. 25/20, Archiv Oddělení dějin hudby MZM.

19 Cenné hudebniny a hudební nástroje daroval archivu tehdejší prelát Prokop Šup.

20 Dne 23. 1. 1920 přímo v klášteře zpracovali část hudebního archivu Vladimír Helfert společně s Janem Kakšem. Oddělili hudební památky lokálního významu od památek významu obecného. Viz zápis o schůzi Rady Hudebního archivu, 23. 1. 1920, Archiv ODH MZM, č. 25/20.

21 Cesta do Napajedel byla podniknuta Vladimírem a Jaroslavem Helfertem 7. 3. 1920 za př́tomnosti zemského konzervátora dr. Dostála. V Archivu Oddělení dějin hudby MZM je dochován protokol o výsledcích téo cesty.

22 Cestu do Brtnice podnikl 11. 3. 1920 Vladimír Helfert za spoluúčasti konzervátora dr. Dostála. V Archivu Oddělení dějin hudby MZM je dochován protokol o výsledcích téo cesty. 
(zámek) ${ }^{23}$ a Moravském Krumlově (zámek), ${ }^{24}$ v Bludově ${ }^{25}$ a Nové Ǩíśi. ${ }^{26} \mathrm{~V}$ následujícím roce byla Vladimírem Helfertem podniknuta např. důležitá cesta do archivu arcibiskupského zámku v Kroměřízii, ${ }^{27} \mathrm{v}$ březnu 1923 pak Helfert navštívil za účelem zjištění hudebních památek Studijní knihovnu v Olomouci.

Jiným důležitým úkolem Rady Hudebního archivu bylo ve spolupráci s MŠANO a přednostou ministerského hudebního oddělení Janem Branbergerem vypracovat a předložit ke schválení systém ochrany hudebních památek pro celou Československou republiku. Na základě již sepsaného Statutu Rady Hudebního archivu Moravského zemského musea v Brně pracovala Rada pod vedením Vladimíra Helferta. Dle dochovaného návrhu zaslaného MŠANO dne 20. ledna $1920^{28}$ mělo dojít ke vzniku Ústřední rady pro ochranu hudebních památek v Československé republice, která by sídlila při Státní konzervatoři hudby v Praze a jejími členy s tříletým mandátem by byli předseda a tři zástupci jednotlivých zemských rad z Prahy, Brna a Bratislavy. Hlavním úkolem Ústřední rady bylo jednotné vedení organizace prací ochranných, soupisových a sběracích a stanovení celkového rámce této činnosti. Statut počítal se zřízením Státního hudebního archivu a muzea v Praze řízeného českou Zemskou radou pro ochranu hudebních památek..$^{29}$ Podobně pak měly být zřízeny zemské rady pro ochranu hudebních památek na Moravě a ve Slezsku se sídlem v Brně (Hudební archiv Moravského zemského muzea) a na Slovensku se sídlem v Bratislavě (nově zř́zený Státní hudební archiv a muzeum).

Se Slovenskem dokonce zahájila Rada Hudebního archivu v Brně na konci roku 1919 jednání poté, co Jan Branberger při jednání v Praze nadhodil otázku připojení Slovenska k Radě Hudebního archivu v Brně. Z tohoto popudu uskutečnil Vladimír Helfert ve dnech 6.-7. prosince 1919 cestu do Bratislavy, ${ }^{30}$ kde se setkal se slovenskými hudebními konzervátory (inspektorem Antonínem Svobodou ze Žiliny a Milanem Lichardem z Bratislavy) a s dalšími představiteli hudebního života v Bratislavě. ${ }^{31}$ Během schůzky refe-

23 Cestu podnikl Vladimír Helfert 29. 4. 1920.

24 Dne 5. 3. 1920 podnikl cestu do Moravského Krumlova konzervátor dr. Dostál. Protokol o výsledku cesty v Archivu ODH MZM.

25 Cestu vykonal roku 1920 Gracian Černušák.

26 Cestu vykonal roku 1920 Jaroslav Helfert.

27 Cestu podnikl Vl. Helfert 22. 2. 1921. Také o výsledku této cesty dochován v Archivu ODH MZM protokol. Pod dohledem Vladimíra Helferta byl v následujících letech pořízen Karlem Vetterlem nový podrobný lístkový katalog arcibiskupské hudební knihovny v Kroměříi dle inovativního katalogizačního systému zavedeném v Hudebním archivu Vl. Helfertem. Viz zprávu o cestě Vladimíra Helferta a Karla Vetterla do Kroměříže dne 25. 6. 1923 v Archivu ODH MZM.

28 Průklep dopisu Rady Hudebního archivu zemského muzea v Brně MŠANO, 20. 1. 1920, Archiv ODH MZM, č. 9/20.

29 Nutno poznamenat, že ke vzniku Státního hudebního archivu nikdy nedošlo. O zřízení této instituce usiloval Vladimír Helfert celý život. Rozsáhlou koncepci podoby takového archivu přeložil veřejnosti ve svém spise Státní hudebně-historický ústav (Praha 1945). Hudební oddělení Národního muzea (dnes České muzeum hudby) bylo založeno až po Helfertově smrti roku 1946 a s jeho budováním se započalo v roce 1948.

30 Zprávu z této cesty podává Rada Hudebního archivu v dopise MŠANO ze dne 10. 12. 1919, Archiv ODH MZM, č. 25/19.

31 Schůzky se dále zúčastnili Miloš Ruppeldt, ředitel Hudební školy v Bratislavě, JUDr. Emanuel Maršík, hudební skladatel a hlavní služný v Bratislavě, a Jindřich Květ, soudce a hudební vědec, žák Zdeňka Nejedlého. 
roval Vladimír Helfert o hudebně konzervátorské práci v brněnském Hudebním archivu. Podníceni Helfertovým referátem se přítomní usnesli organizovat hudebně konzervátorskou práci po vzoru Brna a rozhodli se založit Ústřednu slovenských konzervátorů, jejíž ustavující schůze se měla uskutečnit 10. ledna 1920. Do vedení této slovenské Ústředny pak Vladimír Helfert v přípise MŠANO navrhnul jmenovat věci znalého konzervátora, přičemž doporučoval Jindřicha Květa, případně prof. Dobroslava Orla. Vedení organizace hudebně konzervátorských prací na Slovensku nakonec převzal Jindřich Květ, který dokonce 20. prosince 1919 navštívil brněnský Hudební archiv, aby poznal způsob organizace, katalogizace a zpracovávání hudebních památek. Plánovaný vznik slovenského Ústředního hudebního archivu a muzea v Dolnej Krupej u Trnavy se ovšem nepodařilo realizovat. $^{32}$

Činnost brněnského Hudebního archivu utrpěla po roce 1921 především postupným ochladnutím zájmu ze strany ministerstva. Roku 1921 MŠANO přes několikeré urgence nevyřídilo základní a zásadní návrhy, které mu Rada Hudebního archivu předložila, především návrhy na jmenování konzervátorů, kteří by tvořili sbor pro vybudování Hudebního archivu a návrh na organizaci této práce. Výsledkem intervence Jaroslava Helferta na ministerstvu bylo, že ministerstvo ponechalo Hudebnímu archivu Zemského muzea volnost utvořit si pracovní organizaci podle vlastních potřeb. Úplně odpadl vznik Ústřední rady pro ochranu hudebních památek v Praze, jež měla být původně zřízena, rovněž tak i jmenování konzervátorů a zvláštní subvence na projektovanou dráhu archivu.

Od roku 1922 byl do archivu jako pomocná síla přibrán jeden z prvních studentů Vladimíra Helferta Karel Vetterl, který posléze převzal správu archivu. V roce 1930 došlo k systemizování archivu do organizace Moravského zemského muzea a jeho správou byl pověřen Jan Racek. Přímý podíl Vladimíra Helferta na činnosti archivu se v prủběhu 20. let postupně omezil. Své aktivity Helfert po habilitaci v roce 1921 směřoval zejména k rozvoji nově zřízeného hudebně vědeckého semináře Masarykovy univerzity. I přesto ovšem udržoval čilý kontakt s děním v archivu, o němž byl pravidelně informován svými žáky, kteří se dále na chodu této instituce podíleli. Díky jejich činnosti, ale především zásluhou moderní a inovativní koncepce Vladimíra Helferta se archiv v meziválečných letech zařadil mezi nejvýznamnější a nejmodernější instituce svého druhu v Evropě.

Předložená práce vznikla za finančni podpory Ministerstva kultury v rámci institucionálního financováni na dlouhodobý koncepčni rozvoj výzkumné organizace Moravské zemské muzeum (DKRVO, MK000094862).

Schůzku řídil prof. Bohumil Mathesius, referent o kulturních věcech při ministerstvu s plnou mocí pro Slovensko.

32 Hudobné oddelenie Historického ústavu Slovenského národného múzea vzniklo až v roce 1965. 


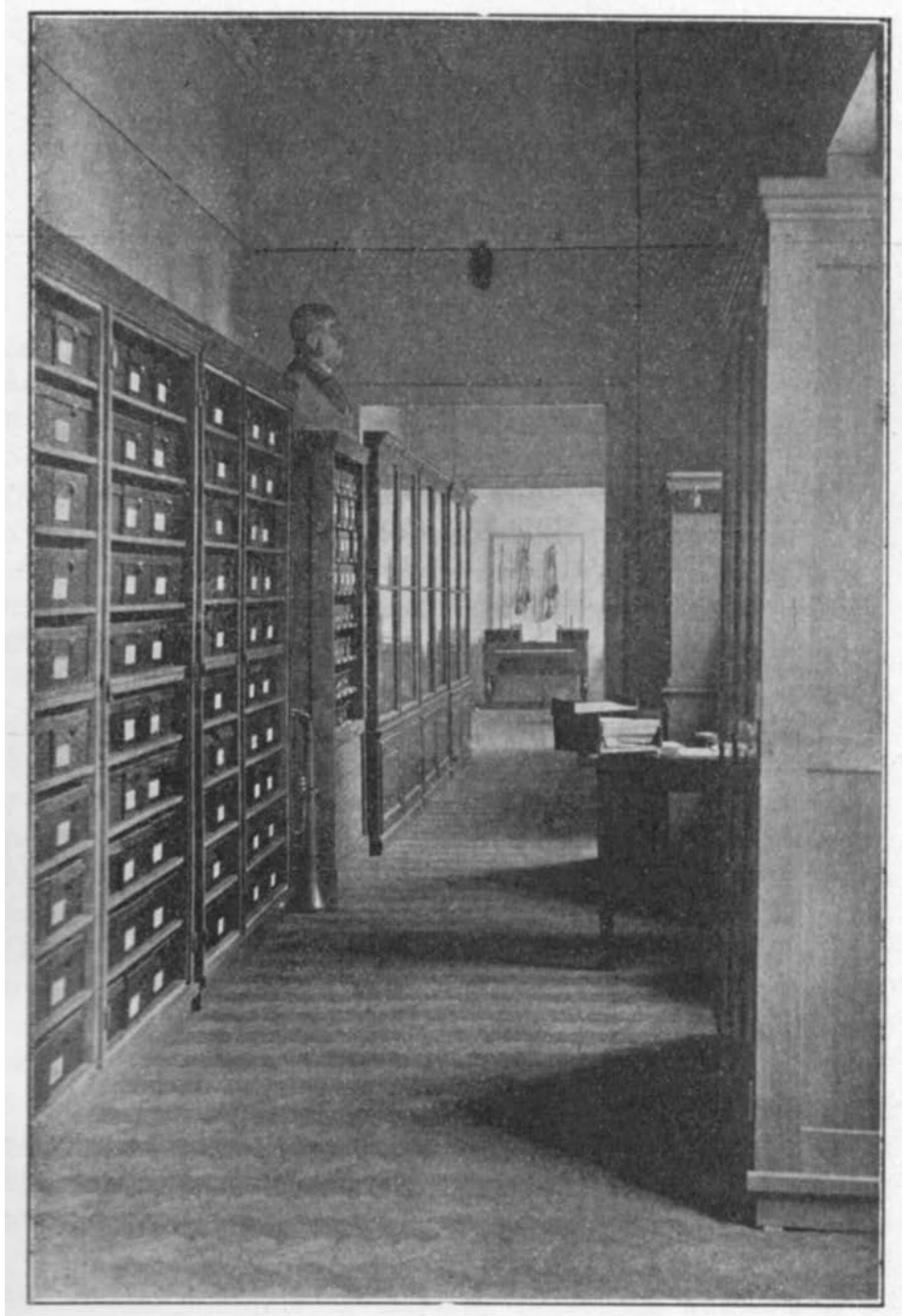

ĊÁST SKLADU HUDEBNIHO ARGHIVU.

Hudební archiv Moravského zemského muzea, 1930. Uloženo v ODH MZM. 


\section{Bibliography}

Archive materials of the Department of the History of Music of the Moravian Museum.

Vladimír Helfert Archive, Department of the History of Music of the Moravian Museum.

HELFERT, Vladimír. Naše hudba a český stát. In HELFERT, Vladimír. Vybrané studie I. O hudebni tvořivosti. Praha: Editio Supraphon, 1970, s. 29-53.

HELFERT, Vladimír. Úkoly české hudební historiografie. Naše věda. Kritický měsičnik 9, 1927-1928, s. 19-27.

HELFERT, Vladimír. Státní hudebně-historický ústav. Praha: Hudební matice Umělecké besedy, $1945,45 \mathrm{~s}$.

HELFERT, Vladimír - UŠÁK, Jaroslav - VETTERL, Karel. Katalog výstavky Hudebniho archivu Zemského musea v Brně. Brno: Nákladem Mor. zem. musea, 1930.

STRAKOVÁ, Theodora. Hudebně historické oddělení Moravského musea v Brně. In Československý hudebni slovnik osob a institucí. Svazek proý. A-L. 1. vyd. Praha: Státní hudební vydavatelství, 1963, s. 505.

VETTERL, Karel. 5 let hudebního archivu Zemského musea moravského v Brně. Věstnik moravského musea 3, 1924, s. 24-30.

VETTERL, Karel. Hudební archiv zemsk. musea. In ČERNUŠÁK, Gracian (red.). Pazdírkĩv hudebni slovnik naučný I. Část věcná. V Brně: Nákladem Ol. Pazdírka, 1929, s. 159. 
